\title{
EIma Üretiminde Pazarlama Etkinliğinin Belirlenmesi Üzerine Bir Araştırma: Isparta Senirkent İlçesi Örneği
}

\author{
Esra ERDOĞAN, Hakan ADANACIOĞLU, M. Çağla ÖRMECI KART* \\ Ege Üniversitesi, Ziraat Fakültesi, Tarım Ekonomisi Bölümü, İzmir
}

Geliş (Received ): 16.09.2015

Kabul (Accepted): 13.04.2016

\begin{abstract}
ÖZET: Türkiye'nin birçok bölgesinde ekonomik anlamda yetiştiriciliği yapılan elmanın eski bir kültür bitkisi olması nedeniyle elma üretiminde pazarlama etkinliğinin belirlenmesi önem taşımaktadır. Bu çalışmada hem dolaylı hem de doğrudan pazarlama kanallarında elma üreticilerinin pazarlama etkinlikleri karşılaştırılmalı olarak incelenmiştir. Bunun yanında çalışmada, üreticilerin pazarlama etkinliğini geliştirmek için kullanılan pazarlama stratejilerine yönelik bazı öneriler getirilmiştir. Bu çalışmanın ana materyalini, Isparta ilinin Senirkent ilçesindeki 88 elma üreticisinden anket yoluyla elde edilen veriler oluşturmaktadır. Pazarlama etkinliği, en genel anlamıyla, pazar çıktısının pazar girdisine oranı olarak tanımlanmakta olup, bu orandaki artış etkinlikte iyileşme olduğunu göstermektedir. Çalışmada elma üreticilerinin etkinliği belirlenirken, Acharya'nın modifiye edilmiş pazarlama etkinliği indeksi formülünden yararlanılmıştır. Pazarlama etkinliği indeksi katsayısının 1'den büyük olması üreticilerin pazarlamada etkin olduğunu göstermektedir. Bu çalışmada pazarlama etkinliği indeksi 0.24 olarak hesaplanmıştır. Pazarlama etkinliği indeksinin 1'den küçük çıkması, elma üreticilerinin kullandığı pazarlama kanallarının etkin olmadığını ortaya koymaktadır. Diğer yandan, üreticilerin doğrudan pazarlama kanallarını kullanması durumunda pazarlama etkinliği indeksinin 3.72 'ye yükseldiği görülmektedir. Elma üreticilerinin pazarlama etkinliğini artırması için doğrudan pazarlama seçeneklerini de tercih etmelerini sağlamak önemli görülmektedir.
\end{abstract}

Anahtar Kelimeler: pazarlama etkinliği, pazarlama, elma, Isparta

\section{A Study on Determination of Marketing Efficiency of Apple Growing: A Case Study of Senirkent District, Isparta}

\begin{abstract}
It is important to identify the marketing efficiency of apple production due to being an old commercially cultural plant growing in many regions of Turkey. In this study direct and indirect marketing channels in terms of the marketing efficiency of apple growers were compared. Additionally some suggestions were made regarding to the marketing strategies for farmers to develop further their marketing efficiency.

The main material of this study was consisted data from 88 apple growers through survey in Senirkent District of Isparta Province. Marketing efficiency is the ratio of marketing input and marketing output in the most general sense; an increase in this ratio signals an improvement in efficiency. In the study Acharya's modified marketing efficiency index formula was used to calculate apple producers' efficiency. If marketing efficiency index is greater than lindicates that producer are effective in marketing. Marketing efficiency index in this study was calculated as 0.24 . When the marketing efficiency index was lower than 1; it would indicate that apple producers were using unefficient marketing channels. On the other hand, if the producers used direct marketing channel, the marketing efficiency index increased to 3.72. It is important to get producer to choose direct marketing options for increasing marketing efficiency of apple producers.
\end{abstract}

Key Words: Marketing efficiency, marketing, apple, Isparta

\section{GİRIȘ}

Elma, dünya üzerinde çok geniş yayılma alanı gösteren ve değişik ekolojilerde üretimi yapılabilen bir meyve türüdür. Elmanın anavatanı Anadolu'yu da içine alan Güney Kafkaslardır. Ekolojik şartların uygunluğu ve gen merkezi olması nedeniyle elma, yurdumuzun hemen her yerinde çok eski ylllardan beri yetiştirilmektedir. Dünya'da elma çeşitlerinin sayısı 6500 'ü aşmaktadır. Türkiye'de ise bu sayı 460'1 bulmaktadır. Elma, içerdiği mineraller ve vitaminler bakımından beslenmede önemli bir yere sahiptir. Taze elma meyvesinin \%84'ünü su, \%16'sını kuru madde teşkil etmektedir. Kuru madde içerisinde karbonhidratlar, proteinler, vitaminler, pektinler ve mineral maddeler yer almaktadır. (Oğuz ve Karaçayır, 2009). Elmanın eski bir kültür bitkisi olması, Türkiye'nin birçok bölgesinde ticari anlamda yetiştiriciliğinin yapılması ve dünyada önemli bir ticari mal olması nedeniyle elma üreticilerinin pazarlama etkinliğinin belirlenmesi önem taşımaktadır.

Günümüzde dünyanın birçok yerinde pek çok insan aç ve kıtlık içerisinde yaşamaktadır. Bunun yanında dünya nüfusunun hızlı bir artış içerisinde olması, yeni tarım alanları açılmasını veya birim alandan daha çok ürün almayı zorunlu kılmaktadır. Yeni tarım alanlarının açılması çeşitli nedenlerden dolayı zor olduğundan, insanoğlu birim alandan daha fazla ürün alma alternatifini tercih etmektedir. Tarımda verimi 
artırmanın bilinen belli başlı yöntemleri vardır. $\mathrm{Bu}$ yöntemler kısaca; fiziki girdi kullanımını artırmak, mekanizasyonu geliştirmek, 1slah metoduyla uygun tohumlar geliştirmek seklinde sıralanabilir. Bu teknik gelişmelerin yanı sıra işletmelerin sosya- ekonomik yapısının ortaya konulması, gerçekleştirilen üretimin kârlılığının ve kullanılan girdi miktarlarının üretime katkısının belirlenmesi, verimi artıran diğer faktörler olarak ortaya çıkmaktadır. Tarımında birim alandan sağlanan ürün miktarının büyük ölçüde doğa koşullarına bağlı olması ve ürünlerin fiyatlarındaki dalgalanmalar, üreticinin gelirini belirsiz kılmaktadır. Bu yüzden tarım sektörü hem teknik hem de işletmecilik alanında gelişme göstermelidir. Aksi takdirde tarımın ülke ekonomisine yaptığı katkılar azalmakta veya etkin olamamaktadır (Altın, 2006).

$\mathrm{Bu}$ çalışmada, Türkiye elma üretiminin \%22'sini gerçekleştiren Isparta ilinin Senirkent ilçesinde elma üretimi yapan işletmelerden elde edilen bilgilerden yola çıkarak elma üreticilerinin pazarlama etkinliği belirlenmiştir. Çalışmanın ilk bölümlerinde esas olarak elma üreticilerinin pazarlama yapısının incelenmiş, elma üreticileri ve işletme yapısına ilişkin özelliklerle elma üretimindeki değişken masraflar ve brüt kâr'a yönelik bilgiler verilmiştir. Çalışmanın son bölümünde ise elma üreticilerinin pazarlama etkinliğine yönelik değerlendirme yapılarak önerilerde bulunulmuştur.

\section{MATERYAL ve METOT}

$\mathrm{Bu}$ çalışmanın ana materyalini, Isparta ilinin Senirkent ilçesinde elma üretimi yapan işletmelerden anket yoluyla elde edilen veriler oluşturmaktadır. Çalışmanın ikincil veri kaynaklarının önemli bir kısmını yurt içinde yapılmış çalışmalar oluşturmaktadır. Çalışmada ayrıca konu ile ilgili yazılmış raporlar ve makalelerden yararlanılmıs, TÜIKK gibi kurumların istatistik veri tabanları kullanılmıştır. İlçeye ait veriler, Senirkent Gıda, Tarım ve Hayvancılık İlçe Müdürlüğü'nden elde edilmiştir.

Çalışmada araştırma alanı olarak Isparta'nın başlıca elma üretim yerlerinden birisi olan Senirkent ilçesi seçilmiştir. 2014 yılı verilerine göre Isparta ilindeki elma üretim alanının \%18'i bu ilçede yer almaktadır (TÜİK, 2015). Senirkent ilçesinde anket çalışmasının gerçekleştirileceği yerin belirlenmesi ise gayeli olarak yapılmış olup bu kapsamda elma üretiminin en yoğun olduğu Merkez ilçe ve Büyükkabaca kasabası seçilmiştir. Örnek hacminin belirlenmesinde oransal örnek hacminden yararlanılmıştır (Newbold, 1995; Miran, 2003).

$$
n=\frac{N p(1-p)}{(N-1) \sigma_{\hat{p}_{x}}^{2}+p(1-p)}
$$

Formülde;

$\sigma_{\mathrm{px}}{ }^{2}=$ oranin varyansin 1

n: örnek hacmi

$\mathrm{N}$ :Anakitle

p: oran (maksimum için 0.5 alınmıștır)
Senirkent Gıda, Tarım ve Hayvancılık İl Müdürlüğü Çiftçi Kayıt Sistemi (ÇKS) kayıtlarına göre \%95 güven aralığı ve $\% 5$ hata payı için örnek hacmi 88 olarak bulunmuştur. Örnek hacminin dağılımı, Merkez ilçe ve Büyükkabaca kasabasının toplam elma üretici sayısı içindeki payı göz önüne alınarak yapılmış olup, buna göre İlçe merkezinde 40, Büyükkabaca kasabasından 48 üretici ile yüz yüze görüşme gerçekleştirilmesine karar verilmiştir. Çalışmanın verileri 2015 yılının Ocak ve Şubat aylarında yapılan anket çalışması ile elde edilmiştir.

Verilerin değerlendirilmesinde çapraz tablolar, ortalama, indeks hesaplamaları ve yüzdelerden yararlanılmıştır. Ayrıca elma üreticilerinin pazarlama marjları ve etkinliği için bir analiz gerçekleştirilmiştir.

Pazarlama marjı, mutlak olarak hesaplanmıștır. Tüketicilerin satın aldığ 1 son ürüne ödeyecekleri fiyat ile üreticilerin ürettikleri ham maddeler için elde ettikleri fiyat arasındaki fark mutlak pazarlama marjı olarak tanımlanmaktadır (İnan, 2006; Adanacığlu, 2014). Araştırmada pazarlama marjları yanında, çiftçilerin pazarlama etkinliği hesaplanmıştır. Pazarlama etkinliği, en genel anlamıyla, pazar çıktısının, pazar girdisine oranı olarak tanımlanmakta olup, bu orandaki artış etkinlikte iyileşme olduğunu göstermektedir (Hussein ve ark., 2013; Adanacioğlu, 2014).

Çalışmada üretici etkinliği belirlenirken Acharya'nın modifiye edilmiş pazarlama etkinliği formülünden yararlanılmıştır (Mutrthy ve ark., 2007; Adanacığlu, 2014).

$\mathrm{MME}=\mathrm{NPF} /(\mathrm{MC}+\mathrm{NMM}+\mathrm{ML})$

$\mathrm{Bu}$ formülde;

MME: Modifiye edilmiş pazarlama etkinliği ölçüsünü;

NPF: Çiftçilerin eline geçen net fiyatı;

MC: Çiftçiler ve aracılar tarafindan yapılan toplam pazarlama masrafinı

NMM: Aracilar tarafindan elde edilen toplam net pazarlama marjinı,

ML: Hasattan tüketiciye ulaşıncaya kadar üründe meydana gelen fiziksel kayıların değerini ifade etmektedir.

Bir işletmenin kullandığı pazarlama kanalında etkin olabilmesi için pazarlama etkinliği indeksi katsayısının 1 'den büyük olması gerekmektedir. Bu katsayı, 1'den ne kadar büyük olursa işletmenin pazarlama kanalındaki etkinliği de o derece artmaktadır. Söz konusu katsayının 1 'den küçük olması ise, işletmenin kullandığı pazarlama kanalının etkin olmadığını ortaya koymaktadır (Longwe ve ark., 2010).

\section{BULGULAR ve TARTIŞMA}

\section{Üreticilerin Sosyo-Demografik Özellikleri}

Milletlerin ekonomik, siyasi ve sosyal yaşamında, nüfusun nitelik ve nicelik bakımından durumu önemli rol oynamaktadır (Esengün, 1990). Ekonomik yaşamın yaratıcısı insan olduğu için nüfus ve ekonomi doğrudan ilişkilidir. 
Nüfus bir taraftan üretimin önemli unsurlarından birisi olan emek arzını meydana getirmekte, diğer taraftan çeşitli mallara karşı talep oluşturmaktadır. Bu nedenle bir ülkenin ekonomik yapısının oluşmasında nüfusun miktarı ve niteliklerinin önemli bir fonksiyonu bulunmaktadır (İnan, 1994). Tarım işletmesi ve üretici ailesi arasında sıkı ve yakın ilișkiler bulunması ve özellikle tarım işletmelerinde kullanılan işgücünün asıl kaynağının aile nüfusu oluşu nedeniyle, incelenen işletmelerdeki nüfus özelliklerinin incelenmesi yararlı görülmektedir (Esengün ve Akay, 1998). İşletmelerin aile nüfus ortalaması 4.23 olarak hesaplanmıştır. Aile nüfusunda erkek nüfusu kadın nüfusundan fazla olduğu saptanmış, hem erkek hem kadın nüfusunun içerisinde ise en fazla 15-49 yaş aralığındaki kişilerin bulunduğu tespit edilmiştir. Ayrıca, 65 yaş üzeri kadın ve erkek sayısının toplam içerisinde çok az bir paya sahip olduğu belirlenmiş̧tir.

Özellikle Türkiye'de tarım, iş ve aile yaşantısını bütünleştiren bir sektör ve bir yaşam biçimidir. Herhangi bir işletmeyi yönetme ve yürütme görevini üstlenmiş bir kişi olan üreticiler, diğer üretim faktörlerinin uygun kombinasyonunu sağlayarak üretimi gerçekleştirmekte, elde ettikleri ürünleri pazarda ve işletmesinde değerlendirerek kâr sağlamakta ve yaptıkları işin sorumluluğunu yüklenerek, riske katlanmaktadırlar. Tarım işletmelerinde kaynakların kullanımındaki etkinliği ve buna bağlı olarak işletme gelirini arttırmada üretici çiftçinin eğitim düzeyi ile tecrübesinin iki önemli etken olduğu anlaşılmıştır. Bu nedenle modern tarımın gerektirdiği hususların basında, şüphesiz çiftçinin eğitilmesi gelmektedir (Karagölge, 1995). Çalışmada işletme yöneticilerinin kişisel niteliklerinin veya sosyal özelliklerinin işletmelerin yönetim biçimi, organizasyonu, teknolojik yenilikleri benimseme ve uygulaması gibi tüm işletme faktörleri üzerinde etkisi olduğu düşüncesinden hareketle (Esengün, 1990), işletme yöneticisinin yaş ve eğitim özellikleri saptanmaya çalışılmıştır. Görüşülen üreticilerin ortalama yaşları 48.65 y1l olarak tespit edilmiş, maksimum yaş 66 yıl ve minimum yaş 29 yıl olarak belirlenmiştir. Üniversite eğitimi almış üreticiler olmakla birlikte üreticilerin eğitim ortalamalarının 8.68 yıl olduğu en düşük eğitim seviyesinin ise 5 y1l olduğu bilgisi elde edilmiştir. Tarımsal üretim deneyiminin en fazla 45 en az 10 yıl olduğu tespit edilmiştir. Tarımsal üretimde ortalama deneyim süresi 26.48 yll olarak, elmada üretim deneyiminin ise 23.42 y1l olarak hesaplanmıştır (Çizelge 1).

Çizelge 1. İncelenen işletmelerde demografik özellikler

\begin{tabular}{lrrrr}
\hline & Ortalama & Standart sapma & Minimum & Maksimum \\
\hline Yaş (yıl) & 48.65 & 9.37 & 29 & 66 \\
Eğitim (yıl) & 8.68 & 3.07 & 5 & 16 \\
Tarımsal üretim deneyimi (yıl) & 26.48 & 9.49 & 10 & 45 \\
Elma üretim deneyimi (yıl) & 23.42 & 9.35 & 7 & 45 \\
Toplam aile nüfusu (kişi) & 4.23 & 1.40 & 2 & 7 \\
Toplam kadın nüfusu (kişi) & 2.08 & 0.85 & 1 & 4 \\
Toplam erkek nüfusu (kişi) & 2.15 & 0.81 & 1 & 4 \\
\hline
\end{tabular}

\section{İșletme Yapısına İlişkin Bulgular}

Tarımsal üretimde kullanılan en önemli doğal kaynak topraktır. Toprak tarım işletmeleri için sadece kuruluş yeri değil, aynı zamanda tarımsal üretimin yapıldı̆̆g alandır (İnan, 1994). Toprak, işletmeyi oluşturan nesnelere egemen durumdadır. Bu nesneler toprağa bağımlıdır ve varlıkları onun işlevi dolayısıyla anlam kazanmaktadır (Aksoy, 1984). Toplam işletme arazisi, üreticinin çalıştığı ve tarımsal üretimi gerçekleştirdiği arazi parçası ya da parçalarının bütünüdür (Esengün ve Akay, 1998). İşletmelerde üretime tahsis edilmiş olan toplam arazi ya da işletme arazisi mülk arazi yanında kira ile tutulan, ortakçılıkla veya diğer şekillerde işletilen araziyi de kapsamaktadır. Çalışmada işletme başına toplam arazi varlığının 41.09 dekar ve maksimum arazi genişliğinin ise 300 dekar olduğu tespit edilmiştir. İşletmedeki arazilerin çoğunun mülk olduğu ve kiraya verilen arazinin bulunmadığ belirlenmiş̧ir. İncelenen işletmelerde işletme başına ortalama 18.83 dekar elma arazisi düştüğünü ve ortalama parsel sayısının 2.31 olduğu görülmüştür (Çizelge 2). Isparta ilinde Demircan ve ark. (2005) tarafından yapılan bir başka çalışmada ise incelenen işletmelerde ortalama elma bahçesi genişliğinin 13.45 da olarak belirlendiği görülmektedir.

Çizelge 2. İncelenen işletmelerde arazi varlığ

\begin{tabular}{|c|c|c|c|c|}
\hline & Ortalama & Standart Sapma & Minimum & Maksimum \\
\hline Toplam işletme arazisi (da) & 41.09 & 42.78 & 7 & 300 \\
\hline Toplam parsel sayıs1 (adet) & 5.63 & 4.23 & 1 & 20 \\
\hline Toplam mülk arazi genişliği (da) & 40.67 & 42.57 & 7 & 300 \\
\hline Toplam ortakçılıkla işlenen arazi genişliği (da) & 0.42 & 2.06 & - & 14 \\
\hline Elma işletme arazisi (da) & 18.83 & 21.42 & 3 & 120 \\
\hline Elma parsel sayısı (adet) & 2.31 & 1.97 & 1 & 10 \\
\hline Elma mülk işletme genişliği (da) & 18.83 & 21.42 & 3 & 120 \\
\hline
\end{tabular}


Araştırma kapsamındaki işletmelerde gelirin en çok elma üretiminden sağlandığı tespit edilmiştir. İşletme başına elmadan elde edilen gelirin ortalama $69838 \mathrm{TL}$ olduğu hesaplanmıştır. İşletmenin toplam geliri içerisinde elma gelirinin payının $\% 42.9$ olduğu belirlenmiştir. Elma gelirini sırasıyla; diğer bitkisel ürün gelirleri (\%38.7), hayvansal üretim gelirleri $(\% 12.2)$, tarım dışı gelirler (\%3.5), diğer gelirler (\%2.5) ve tarımsal desteklerin $(\% 0.4)$ takip ettiği saptanmıştır
(Çizelge 3). Diğer bitkisel ürün gelirleri içerisinde yer alan başlıca ürünler kiraz, üzüm, şekerpancarı ve arpadır. Hayvansal üretim geliri içinde ise özellikle küçükbaş hayvan besiciliği önemli bir yer tutmaktadır. Söz konusu işletmelerin gelirleri içerisinde tarımsal desteklemeler de yer almakla birlikte çok fazla bir yer tutmamaktadır. Alınan desteklerin daha çok tarımsal girdi kullanımı üzerine olduğu görülmektedir.

Çizelge 3. İncelenen ișletmelerde gelir dağılımı

\begin{tabular}{lrrrr}
\hline & Ortalama gelir (TL) & Gelir içerisindeki payı (\%) & Standart sapma & Maksimum \\
\hline Elma geliri & 69838.24 & 42.9 & 73950.75 & 446750 \\
Diğer bitkisel ürün geliri & 63011.59 & 38.7 & 64004.58 & 334100 \\
Hayvansal üretim geliri & 19816.48 & 12.2 & 63452.71 & 504000 \\
Tarım dışı gelir & 5679.09 & 3.5 & 8305.97 & 36000 \\
Diğer gelirler & 4035.68 & 2.5 & 9884.21 & 79200 \\
Tarımsal destekler & 599.49 & 0.4 & 1457.51 & 10000 \\
Toplam & 162980.57 & 100.00 & 134364.98 & 682500 \\
\hline
\end{tabular}

Anket uygulanan işletmelerde, işletme başına ortalama 18.83 dekar elma arazisi düştüğü hesaplanmıștır. $\mathrm{Bu}$ elma arazisinin çeşitlere göre dağılımı incelendiğinde ilk sırada ortalama 11.04 dekar ile toplam elma alanın \%58.63'ünü kaplayan Starking Delicious çeşidinin yer aldığ 1 belirlenmiştir. Bunu sırasiyla \%28.36 ile Golden Delicious (5.34 dekar),
\%10.20 ile Granyy Smith (1.92 dekar), \%2.12 Pink Lady (0.40 dekar) ve \%0.69 ile Red Chief (0.13 dekar) çeşitlerinin takip ettiği saptanmıştır (Çizelge 4). Demircan ve ark. (2005) tarafindan yapılan çalışmada da üreticilerin elma üretiminde çoğunlukla "Golden ve Starking" çeşitlerini tercih ettiği belirtilmiştir.

Çizelge 4. İncelenen işletmelerde yetiștirilen elma çeșitleri (dekar)

\begin{tabular}{|c|c|c|c|c|c|}
\hline & Ortalama & Standart sapma & Minimum & Maksimum & $\%$ \\
\hline Starking Delicious & 11.04 & 11.73 & 1 & 90 & 58.63 \\
\hline Golden Delicious & 5.34 & 9.29 & 1 & 80 & 28.36 \\
\hline Granny Smith & 1.92 & 4.63 & - & 30 & 10.20 \\
\hline Pink Lady & 0.40 & 1.87 & - & 10 & 2.12 \\
\hline Red Chief & 0.13 & 1.17 & - & 11 & 0.69 \\
\hline Toplam & 18.83 & 21.42 & 3 & 120 & 100.00 \\
\hline
\end{tabular}

İşletmelerde Elma Üretimine İlişkin Değişken Masraflar ve Brüt Kar

İncelenen işletmelerdeki elma üretimine ilişkin değişken masraf unsurları Çizelge 5'te gösterilmiştir. Elma üretim faaliyeti oldukça ișlem gerektiren bir üretim koludur. İncelenen işletmelerde ortalama 1.95 kez toprak işleme yaptığı, toprak işlemede genellikle diskaro ve pulluk kullanıldığı, işgücü kullanımının çeki gücü kullanımına göre düşük olduğu saptanmıştır. İşletme başına işgücü tutarının ise çeki gücü tutarından fazla olduğu hesaplanmıș, toprak işleme masrafi, ișletme bașina ortalama $16.12 \mathrm{TL} \quad \mathrm{da}^{-1}$ olarak belirlenmiștir.

İşletmelerde ortalama $1.25 \mathrm{kez}$ el çapası ile çapalama yaptığ 1 tespit edilmiștir. Çünkü çapalama genellikle ağaç diplerine yapılmakta ve makinelerin ağaç dibine girmesi zor olduğundan burada is gücüne daha çok ihtiyaç duyulduğu saptanmıştır. Çeki gücünün ise sadece iş̧ileri getirip götürmede kullanıldığı belirlenmiștir. Buna paralel olarak da is gücü ihtiyacının çapalamada $4.27 \mathrm{saat} \mathrm{da}^{-1}$, çeki gücü ihtiyacının ise 0.21 saat $\mathrm{da}^{-1}$ olduğu hesaplanmıştır. İşletme başına çapalama masrafları ise ortalama $32.04 \mathrm{TL} \mathrm{\textrm {da } ^ { - 1 }}$ olarak belirlenmiştir. Elma üretiminde en önemli işlemlerden biri gübreleme olup, toplam masraflar içinde ilaçlamadan sonra ikinci sırada yer aldığı belirlenmiştir. İşletme başına $2.38 \mathrm{kez}$ yapılan gübreleme işleminde genellikle makine kullanımının yaygın olduğu saptanmıştır. İncelenen işletmelerde damla sulama ile gübreleme yapan üretici bulunmadığı tespit edilmiştir. Gübreleme işleminde ortalama çeki gücü ile işgücü kullanımının 0.55 saat da-1 ile birbirine eşit olduğu belirlenmiştir. Gübrelemede işgücü tutarının $15.85 \mathrm{TL}$ $\mathrm{da}^{-1}$, çeki gücü tutarının ise $3.05 \mathrm{TL} \mathrm{da}{ }^{-1}$ olduğu hesaplanmıştır. Araştırmada toplam gübre ve gübreleme masrafının işletme başına $106.32 \mathrm{TL} \mathrm{\textrm {da } ^ { - 1 }}$ olduğu saptanmıștır ve toplam masrafların \%14.57'sini oluşturduğu belirlenmiștir.

Araştırma kapsamındaki işletmelerde toplam masraflar içinde ilk sırayı ilaçlama nmasraflarının aldığı belirlenmiștir. İșletme başına ortalama 14 kez ilaçlama yapıldığı ve ilaçlama masrafının dekara $345.44 \mathrm{TL}$ 
olduğu hesaplanmıştır. Isparta ilinde yapılan bir diğer çalışmada ise işletme başına ilaçlama sayısı $12.43 \mathrm{kez}$ olarak belirlenmiştir (Demircan ve ark., 2005). İlaçlama pulverizatör ile yapılmakta olup, iş gücü kullanımının 2.66 saat $\mathrm{da}^{-1}$, çeki gücü kullanımının $2.97{\text { saat } \mathrm{da}^{-1}}^{-1}$ olarak hesaplanmıştır. İlaçlama işleminde işletme başına ortalama işgücü tutarı $90.23 \mathrm{TL} \mathrm{da}^{-1}$, çeki gücü tutarı ise 12.14 $\mathrm{TL} \mathrm{da}^{-1}$ olarak saptanmıştır.

İncelenen işletmelerde sulamanın damla sulama ile yapıldı̆̆ belirlenmiştir. İşletme başına 4.96 kez yapplan sulamanın, işletme başına ortalama masrafı 101.64 TL $\mathrm{da}^{-1}$ olarak hesaplanmıştır. İşletme başına ortalama 0.88 kez yapılan budama işleminin toplam masrafinın işletme başına $49.89 \mathrm{TL} \mathrm{da}^{-1}$ olduğu saptanmıştır. İşletmelerin çoğunun yabancı ot temizliği yapmadığı, yabancı ot temizliği yapan işletmelerde de makine ve tırpan kullanıldığı belirlenmiş̧tir. İşletme başına yabancı ot temizleme masrafı $5.41 \mathrm{TL} \mathrm{da}^{-1}$ olarak hesaplanmıştır. Araştırma kapsamında yeralan işletmelerde meyve seyreltmenin ortalama $0.53 \mathrm{kez}$ yapıldı $\breve{g} 1$, seyreltme masrafi ise işletme başına $18.10 \mathrm{TL} \mathrm{da}^{-1}$ olduğu hesaplanmıştır. Meyve seyreltmenin işgücüne dayalı olduğu, birçok işletmenin ürünlerini daldan sattıkları için meyve seyreltme işlemini yapmamayı tercih ettikleri gözlemlenmiştir. Seyreltme işleminde ortalama iş gücü tutar1 $17.69 \mathrm{TL} \mathrm{da}^{-1}$ olarak hesaplanmıştır. Görüşülen işletmelerin çoğunda hasat yapılmadığı, işletmelerin genellikle meyveyi çiçek döneminde ya da meyve döneminde sattıkları tespit edilmiștir. $\mathrm{Bu}$ nedenle, ortalama olarak hasat masraflarının işletme başına $39.57 \mathrm{TL} \mathrm{da}^{-1}$ olduğu ve toplam masraflar içersinde \%5.42 gibi düşük bir paya sahip olduğu görülmektedir. İncelenen işletmelerde hasatta genellikle işgücü kullanıldığı, makine gücüyle hasat yapmanın günümüz koşullarında mümkün olmadığı belirlenmiştir. İşletmelerde hasatta kullanılan ortalama işgücü tutarı 32.30 TL da ${ }^{-1}$ ve çeki gücü tutarı $0.41 \mathrm{TL} \mathrm{da}^{-1}$ olarak hesaplanmıştır. İncelenen işletmelerde taşıma masraflarının payının toplam masraflar içerisinde oldukça düşük olduğu belirlenmiştir. İşletmelerin çoğunda hasat yapılmadığından taşıma da yapılmadı tespit edilmiştir. İşletme başına taşıma masrafları 15.36 $\mathrm{TL} \mathrm{da}^{-1}$ olarak hesaplanmıştır

Çizelge 5. İşletmelerde elma üretim maliyeti

\begin{tabular}{|c|c|c|c|c|c|c|c|c|c|}
\hline & $\begin{array}{l}\text { Kaç kez } \\
\text { yapıldığı }\end{array}$ & Ekipman & $\begin{array}{c}\text { İsgücü } \\
\left(\text { saat } \mathrm{da}^{-1}\right)\end{array}$ & $\begin{array}{c}\text { İşgücü } \\
\text { tutar } \\
\left(\mathrm{TL} \mathrm{da}^{-1}\right)\end{array}$ & $\begin{array}{l}\text { Çekigücü } \\
\left({\left.\text { saat } \mathrm{da}^{-1}\right)}^{-1}\right)\end{array}$ & $\begin{array}{l}\text { Çekigücü } \\
\text { tutar } \\
\left(\mathrm{TL} \mathrm{da}^{-1}\right)\end{array}$ & $\begin{array}{l}\text { Materyal } \\
\text { Masrafi } \\
\left(\mathrm{TL} \mathrm{da}^{-1}\right)\end{array}$ & $\begin{array}{c}\text { Toplam } \\
\text { Masraf } \\
\left(\mathrm{TL} \mathrm{da}^{-1}\right)\end{array}$ & $\begin{array}{c}\text { Oran } \\
(\%)\end{array}$ \\
\hline $\begin{array}{l}\text { Toprak } \\
\text { ișleme }\end{array}$ & 1.95 & $\begin{array}{c}\text { Diskaro + } \\
\text { Pulluk }\end{array}$ & 0.37 & 12.87 & 0.50 & 3.25 & - & 16.12 & 2.21 \\
\hline Çapalama & 1.25 & El çapası & 4.27 & 31.01 & 0.21 & 1.03 & - & 32.04 & 4.39 \\
\hline Gübreleme & 2.38 & Makine & 0.55 & 15.85 & 0.55 & 3.05 & 87.42 & 106.32 & 14.57 \\
\hline İlaçlama & 13.99 & Pulverizatör & 2.66 & 90.23 & 2.97 & 12.14 & 243.07 & 345.44 & 47.33 \\
\hline Sulama* & 4.69 & $\begin{array}{l}\text { Damla } \\
\text { sulama }\end{array}$ & - & - & - & - & 101.64 & 101.64 & 13.93 \\
\hline Budama & 0.88 & $\begin{array}{c}\text { Budama } \\
\text { makas1 }\end{array}$ & 6.71 & 49.24 & 0.11 & 0.65 & - & 49.89 & 6.84 \\
\hline Ot temizliği & 0.59 & $\begin{array}{c}\text { Makine + } \\
\text { Tirpan }\end{array}$ & 0.36 & 4.87 & 0.09 & 0.54 & - & 5.41 & 0.74 \\
\hline Seyreltme & 0.53 & El ile & 2.89 & 17.69 & 0.07 & 0.41 & - & 18.10 & 2.48 \\
\hline Hasat & 0.43 & El ile & 6.01 & 32.30 & 0.08 & 0.41 & 6.86 & 39.57 & 5.42 \\
\hline Taşıma & 0.33 & $\begin{array}{l}\text { Traktör } \\
\text { römork }\end{array}$ & 0.03 & 13.82 & 0.12 & 0.59 & 0.95 & 15.36 & 2.10 \\
\hline Deği & Masraflar T & $\mathrm{m} 1$ & 23.85 & 267.88 & 4.7 & 22.07 & 439.94 & 729.89 & 100.0 \\
\hline
\end{tabular}

Değișen Masraflar Toplamı

$23.85 \quad 267.88$

$4.7-22.07$

\begin{tabular}{lrr}
439.94 & 729.89 & 100.0 \\
\hline raf grubunda & sadece su bedeli olara
\end{tabular} *üreticiler uyguladıkları damla
materyal masrafı yer almaktadı.

Çizelge 6'da incelenen işletmelerdeki elma üretimine ilişkin brüt kar hesaplamaları yer almaktadır. İncelenen ișletmelerde elma üretiminde ortalama verim $4877.07 \mathrm{~kg} \mathrm{da}^{-1}$, ortalama satış fiyatı $0.87 \mathrm{TL} \mathrm{kg}^{-1}$ ve dekara Gayri Safi Üretim Değeri 4243.05 TL olarak hesaplanmıştır. Isparta ilinde yapılan bir diğer çalışmada işletmelerde ortalama elma verimi $2939 \mathrm{~kg}$ $\mathrm{da}^{-1}$ olarak belirlenmiştir (Demircan ve ark., 2005). Bu sonuca göre, araştırma bölgesinde elma üretiminde hesaplanan verimin diğer bölgeler ile kıyaslandığında daha yüksek olduğu ifade edilebilir.

Araştırma kapsamındaki işletmelerde dekara değişen masraflar dekara 729.88 TL olarak hesaplanmıştır. Brüt kâr işletmede mevcut kit üretim faktörlerinin rekabet güçlerinin belirlenmesinde kullanılan önemli bir başarı ölçüsüdür (Demircan ve ark., 2005). Elma üretiminde dekara brüt kâr 3513.17 TL olarak tespit edilmiştir. İncelenen işletmelerde değişen masraflar ve brüt kâr 1 $\mathrm{kg}$ elma içinde hesaplanıp Çizelge 6'da sunulmuştur. İşletmeler $1 \mathrm{~kg}$ elma üretmek için $0.15 \mathrm{TL}$ değişen masraf yapmakta ve satış fiyatı olan 0.87 TL'den değişen masraf çıkarıldığında, 1 kg elmanın brüt kârı 0.72 TL olmaktadır.

Çizelge 6. İncelenen işletmelerde elma üretiminde masraf ve gelir unsurlar

\begin{tabular}{|c|c|}
\hline Masraf ve Gelir Unsurları & Değer \\
\hline Verim $\left(\mathrm{kg} \mathrm{da}^{-1}\right)$ & 4877.07 \\
\hline Satış Fiyatı $\left(\mathrm{TL} \mathrm{kg}^{-1}\right)$ & 0.87 \\
\hline Gayrisafi Üretim Değeri (TL da $\left.{ }^{-1}\right)$ & 4243.05 \\
\hline Değişen Masraflar $\left(\mathrm{TL} \mathrm{da}^{-1}\right)$ & 729.88 \\
\hline Brüt Kâr $\left(\mathrm{TL} \mathrm{da}^{-1}\right)$ & 3513.17 \\
\hline Değişen Masraflar $\left(\mathrm{TL} \mathrm{kg}^{-1}\right)$ & 0.15 \\
\hline Brüt Kâr (TL kg $\left.{ }^{-1}\right)$ & 0.72 \\
\hline
\end{tabular}




\section{İncelenen İşletmelerde Pazarlama Yapıst}

Anket uygulanan üreticilerden alınan verilere göre en çok tercih edilen elma satış biçiminin \%37.5 ile kilo hesabıyla toptan satış olduğu belirlenmiştir. Bunu sırasıyla meyve döneminde ağaç üzerinden götürü satış olarak da bilinen kabala satış (\%34.1), çiçek döneminde kabala (\%27.3) ve perakende satış (\%1.1) takip etmiştir (Çizelge 7).

Araştırma kapsamındaki işletmelerin sadece bir tanesinin doğrudan pazarlama yaptığı ve bu şekilde sattığ1 elma miktarın $2550 \mathrm{~kg}$ olduğu belirlenmiştir. Bu üreticinin toplam satı̧s içerisindeki payı $\% 0.04$ olarak hesaplanmıştır. Üreticiler tarafindan en çok tercih edilen satış biçimi kilo hesabıyla toptan satıș olmasına rağmen üretilen elmaların \%40.33'ünün meyve döneminde toptan olarak satıldığı belirlenmiş̧tir. Görüşülen üreticilerin \%62.36'sının satışın yapıldığı kişiden önceden avans aldığı, \%37.50'sinin ise önceden avans almadığı belirlenmiştir.

Çizelge 7. İncelenen işletmelerde elma satıs biçimleri (\%)

\begin{tabular}{lcccc}
\hline & $\begin{array}{c}\text { Üretici } \\
\text { sayısı }\end{array}$ & $\%$ & $\begin{array}{c}\text { Satılan elma } \\
\text { miktarı }(\mathrm{kg})\end{array}$ & $\begin{array}{c}\text { Toplam satış } \\
\text { içerisindeki payı }(\%)\end{array}$ \\
\hline Kilo hesabıyla toptan & 33 & 37.5 & 1958400 & 27.29 \\
Meyve döneminde kabala* & 30 & 34.1 & 2893200 & 40.33 \\
Çiçek döneminde kabala* & 24 & 27.3 & 2320500 & 32.34 \\
Perakende satış (doğrudan tüketici) & 1 & 1.1 & 2550 & 0.04 \\
\hline Toplam & 88 & 100.0 & 7174650 & 100.00 \\
\hline *kabala satış: ürün miktarının ölçülüp tartılmadan satılması & & &
\end{tabular}

İncelenen işletmelerin genel olarak elma satışında toptan satış biçimini tercih etme nedenleri incelendiğinde, peșin para almaları en etkili faktör; taşıma masrafi düşük veya olmuyor ifadesi ise en az etkili faktör olarak tespit edilmiştir (Çizelge 8). Üreticiler peșin para alabildikleri için ürünlerini daha düşük fiyatla olsa da toptan satmayı tercih etmektedirler. Çünkü diğer satı̧s biçimlerinde çekin/senetin karşılıksız çıkması, vade süresinin beklenmesi veya parayı alamama gibi olumsuz deneyimler yaşadıklarını belirtmişlerdir.

Çizelge 8. İşletmelerin toptan satış biçimini tercih etme nedenleri

\begin{tabular}{lcc}
\hline & $\begin{array}{c}\text { Likert } \\
\text { Ort.* }\end{array}$ & $\begin{array}{c}\text { Std } \\
\text { Sapma }\end{array}$ \\
\hline Peşin para alabilmesi & 4.38 & 1.03 \\
Riskinin daha az olması & 4.23 & 0.82 \\
Fiyatının yüksek olması & 4.22 & 1.53 \\
Ürün miktarını tam olarak hesaplayabilmesi & 4.13 & 0.95 \\
İşgücü maliyetinin düşük olması & 4.07 & 0.89 \\
Taşıma masrafı düşük veya olmuyor & 3.89 & 0.69 \\
\hline *1:kesinlikle katılmıyorum 2:katılmıyorum 3:kararsızım 4:katılıyorum
\end{tabular}

5:kesinlikle katıliyorum

Satış kanalının tercihinde en etkili faktörün güvenilir olması; en az etkili faktörün ise sözleșmeli üretim yaptığım için ifadesi olduğu tespit edilmiștir (Çizelge 9). Aynı satış biçimini tercih etmelerinde olduğu gibi üreticiler ödeme alamama korkusu yaşamamak için güvenilir satış kanallarını en etkili faktör olarak ilk sıraya koymuşlardır.

Çizelge 9. İşletmelerin tüccarlar1/komisyoncuları tercih nedenleri

\begin{tabular}{|c|c|c|}
\hline & $\begin{array}{c}\text { Likert } \\
\text { Ort.* }\end{array}$ & $\begin{array}{c}\text { Std. } \\
\text { Sapma }\end{array}$ \\
\hline Güvenilir olmas1 & 4.76 & 0.69 \\
\hline Peşin ödeme yapması & 4.50 & 0.73 \\
\hline Fiyatın yüksek olması & 4.28 & 0.87 \\
\hline Geçmiş yıllarda ürününü almış olması & 4.24 & 0.93 \\
\hline Taşıma masrafı düşük veya olmuyor & 3.99 & 1.57 \\
\hline Sözleşmeli üretim yaptığım için & 2.07 & 1.28 \\
\hline
\end{tabular}
4:katılıyorum 5:kesinlikle katılıyorum

\section{Incelenen İșletmelerde Üretici Eline Geçen} Fiyatlar

İncelenen işletmelerde elma üreticilerinin eline geçen brüt ve net fiyatlar Çizelge 10 'da verilmiştir. Çizelgeden de görüleceği üzere, doğrudan pazarlamada üreticinin eline geçen net fiyat $1.97 \mathrm{TL} \mathrm{kg}^{-1}$ olarak hesaplanmıştır. Bu hesaplamada brüt fiyat $2.5 \mathrm{TL} \mathrm{kg}^{-1}$, toplam pazarlama masrafi $0.50 \mathrm{TL} \mathrm{kg}^{-1}$ ve hasat sonrasi kayıp $0.03 \quad \mathrm{TL} \quad \mathrm{kg}^{-1}$ olarak saptanmıştır. Dolaylı pazarlamada ise üreticinin eline geçen net fiyat $0.83 \mathrm{TL}$ $\mathrm{kg}^{-1}$ olarak belirlenmiştir. Bu hesaplamada brüt fiyat $0.86 \mathrm{TL} \mathrm{kg}^{-1}$, toplam pazarlama masrafi $0.02 \mathrm{TL} \mathrm{kg}^{-1} \mathrm{ve}$ hasat sonrası kayıp $0.01 \mathrm{TL} \mathrm{kg}^{-1}$ olarak tespit edilmiştir.

Çizelge 10. İncelenen işletmelerde doğrudan ve dolaylı pazarlamada üreticilerin eline geçen brüt ve net fiyatlar

\begin{tabular}{lcc} 
& $\begin{array}{c}\text { Doğrudan Pazarlama } \\
\text { (Tüketici) }\end{array}$ & $\begin{array}{c}\text { Dolaylı Pazarlama } \\
\text { (Tüccar/ Komisyoncu) }\end{array}$ \\
\hline Brüt fiyat $\left(\mathrm{TL} \mathrm{kg}^{-1}\right)(1)$ & 2.50 & 0.86 \\
Toplam pazarlama masraflar1 $\left(\mathrm{TL} \mathrm{kg}^{-1}\right)(2)^{*}$ & 0.50 & 0.02 \\
Hasat sonrası kayıp $\left(\mathrm{TL} \mathrm{kg}^{-1}\right)(3)^{* *}$ & 0.03 & 0.01 \\
Net fiyat $\left(\mathrm{TL} \mathrm{kg}^{-1}\right)\{1-(2+3)\}$ & 1.97 & 0.83 \\
\hline
\end{tabular}

*Taşıma, taşıma işçiliği, paketleme, depolama, komisyoncu ve diğer pazarlama masrafları

**Hasat sonrası kayıp oranının hesaplanmasında \%1.25 alınmıștır. 


\section{İncelenen İşletmelerde Elma Üretiminde Pazarlama Etkinlǐ̆i}

Araştırma kapsamındaki ișletmelerde elma üretimi için doğrudan pazarlama etkinliği indeksi Çizelge 11 'de verilmiştir. Pazarlama etkinliği hesaplanırken net fiyat $1.97 \mathrm{TL} \mathrm{kg}^{-1}$, toplam pazarlama masrafi $0.50 \mathrm{TL} \mathrm{kg}{ }^{-1}$, hasat sonrası kayıp $0.03 \mathrm{TL} \mathrm{kg}^{-1}$ olarak, net pazarlama marjı doğrudan tüketiciye satış söz konusu olduğu için sıfir olarak göz önüne alınmış ve doğrudan pazarlama etkinliği indeksi 3.72 olarak hesaplanmıştır.

Çizelge 11. İncelenen işletmelerde doğrudan pazarlama etkinliği indeksi

\begin{tabular}{lc}
\hline & $\begin{array}{c}\text { Doğrudan } \\
\text { Tüketici }\end{array}$ \\
\hline Net fiyat $\left(\mathrm{TL} \mathrm{kg}^{-1}\right)(1)$ & 1.97 \\
Toplam pazarlama masrafları $\left(\mathrm{TL} \mathrm{kg}^{-1}\right)(2)$ & 0.50 \\
Hasat sonrası kayıp $(\mathrm{TL} \mathrm{kg}$ & $*(3)$ \\
Net Pazarlama Marjı $(4)$ & 0.03 \\
Pazarlama Etkinliği İndeksi $\{1 /(2+3+4)\}$ & - \\
\hline *Hasat sonrası kayıp oranının hesaplanmasında \%1.25 alınmıştır.
\end{tabular}

Üreticilerin elma üretimi için dolaylı pazarlamadaki etkinliği için hesaplanan indeks ise Çizelge 12 'de verilmiştir. Pazarlama etkinliği hesaplanırken net fiyat $0.83 \mathrm{TL} \mathrm{kg}^{-1}$, tüketiciye satış fiyatı $4.30 \mathrm{TL} \mathrm{kg}{ }^{1}$, araciların toplam pazarlama marji $3.47 \mathrm{TL} \mathrm{kg}^{-1}$, üreticilerin toplam pazarlama masrafi $0.02 \mathrm{TL} \mathrm{kg}^{-1}$ alınmış ve pazarlama etkinliği indeksi 0.24 olarak hesaplanmıştır. Pazarlama etkinliği indeksinin 1'den kü̧̈ük çıkması, elma üreticilerinin kullandığı pazarlama kanallarının etkin olmadığını ortaya koymaktadır.

Çizelge 12. İncelenen işletmelerde dolaylı pazarlama etkinliği indeksi

\begin{tabular}{lc}
\hline & $\begin{array}{c}\text { Dolaylı } \\
\text { Pazarlama }\end{array}$ \\
\hline Net fiyat $\left(\mathrm{TL} \mathrm{kg}^{-1}\right)(1)$ & 0.83 \\
Tüketiciye satış fiyatı $\left(\mathrm{TL} \mathrm{kg}^{-1}\right) *(2)$ & 4.30 \\
Aracıların toplam pazarlama marjı $\left(\mathrm{TL} \mathrm{kg}^{-1}\right)$ & 3.47 \\
$(\mathrm{NMM+MC})(3=2-1)$ & \\
Üreticinin toplam pazarlama masrafi $\left(\mathrm{TL} \mathrm{kg}^{-1}\right)$ & 0.02 \\
$\left(\mathrm{MC}_{\text {üretici }}\right)(4)$ & 0.24 \\
Pazarlama Etkinliği İndeksi $\{1 /(3+4)\}$ & \\
\hline *Marketlerdeki elma satıs fiyatlarının ortalaması dikkate alınmıstır.
\end{tabular}

Hindistan'da üzüm yetiştiriciliğinde Acharya'nın modifiye edilmiş pazarlama etkinliği farklı satış kanallarında 0.99 ile 1.15 arasında bulunmuştur (Dastagiri ve ark., 2010). Pakistan'da yapılan bir diğer çalı̧̧ada ise meyvelerin pazarlama etkinliği indeksinin sebzelere göre daha yüksek olduğu vurgulanmış aynı çalışmada mango meyvesinde farklı kanallarda pazarlama etkinliği indeksi 4.08 ile 4.35 arasında; muzda ise 2.66 ile 3.17 arasında hesaplandı $\breve{~} 1$ görülmüştür. (Hassan, 2013). Hindistan'ın Andra Pradesh ve Karnataka şehirlerinde yapılan bir başka çalışmada ise pazarlama etkinliği indeksi mangoda 0.85 ; üzümde 2.13; muzda 1.12 ve narda 1.01 olarak hesaplanmıştır (Murthy ve ark., 2009). Bu bilgilere göre değerlendirme yapıldığında, elma üretiminde dolaylı pazarlama etkinliği indeksi oldukça düşüktür. Diğer bir ifadeyle, elma üreticilerin kullandığı dolaylı pazarlama kanalları etkin değildir. Pazarlama etkinliği indeksine göre bu iki pazarlama sisteminden, doğrudan pazarlama siteminin üreticiler açısından avantajlı olduğu görülmektedir.

\section{SONUC}

Çalışma sonucunda elma üretiminde doğrudan pazarlama ve dolaylı pazarlama etkinliği saptanmıştır. Çalışma sonucuna göre doğrudan pazarlama etkinliği 3.72, dolaylı pazarlama etkinliği 0.24 olarak bulunmuştur. Araştırma bulgularına göre, pazarlama etkinliği indeksine göre bu iki pazarlama sisteminden doğrudan pazarlama sistemi seçilmelidir. Çünkü doğrudan pazarlamada üretici ile tüketici arasındaki pazarlama marjını sıfıra indirerek hem tüketici hem de üretici için avantaj sağlamaktadır. Ancak üreticinin bireysel olarak elindeki ürünlerini hepsini doğrudan tüketiciye pazarlaması mümkün olmayacaktır. $\mathrm{Bu}$ nedenle doğrudan pazarlamadaki bu fiyat avantajını korumak için üreticilerin kooperatif kurmaları sağlanmalı ve ürettikleri ürünlerin bir kısmını okul, hastane, bakımevleri gibi toplu yerlere doğrudan pazarlamaları teşvik edilmelidir. Dolaylı ya da geleneksel pazarlamada ise üretici- tüketici arasındaki pazarlama marjı oldukça fazladır. $\mathrm{Bu}$ sebeplerden dolayı, doğrudan pazarlamanın daha iyi olduğu sonucuna ulaşılmaktadır.

\section{KAYNAKLAR}

Adanacıŏglu, H. 2014. Tarımsal Üretimde Doğrudan Pazarlama Kavramı ve Pazarlama Etkinliği Açısından Dolaylı Pazarlama Karşılaştırılmalı Analizi: İzmir İli Urla İlçesi Balıklıva Köyü Örneği. XI. Ulusal Tarım Ekonomisi Kongresi, 3-5 Eylül, Samsun.

Aksoy, S. 1984. Tarım Hukuku. Ankara Üniversitesi, Ziraat Fakültesi, Yayın No: 907, Ankara.

Altın, Ö. 2006. Tokat İli Merkez İlçede Vişne Yetiştiriciliği Yapan Tarım İşletmelerinin Ekonomik Analizi, Üretim ve Pazarlama Sorunları. GOP Fen Bil. Enst., Tarım Ekonomisi ABD, Yüksek Lisans Tezi, 123s.

Dastagiri, M.B., Ganesh Kumar, B., Hanumanthaiah, C.V., Paramsivam, P., Sidhu, R.S., Sudha, M., Mandal, S., Singh, B., Chand, K. 2010. Estimation of Marketing Efficiency of Horticultural Commodities under Different Supply Chains in India. National Centre for Agricultural Economics and Policy Research Project Report, New Delhi.

Demircan, V., Yılmaz, H., Binici, T. 2005. Isparta İlinde Elma Üretim Maliyeti ve Gelirinin Belirlenmesi. Tarım Ekonomisi Dergisi, 11(2):7180. 
Esengün, K. 1990. Tokat İlinde Meyve Yetiştiriciliğ Yapan İşletmelerin Ekonomik Durumu ve İşletme Sonuçlarını Etkileyen Faktörlerin Değerlendirilmesi Üzerine Bir Araştırma. EÜ Fen Bil. Enst., Tarım Ekonomisi ABD, Doktora Tezi, $256 \mathrm{~s}$.

Esengün, K., Akay, M. 1998. Tokat İli Artova Bölgesi Tarım İşletmelerinin Yapısal Analizi ve Faaliyet Sonuçları. Gaziosmanpaşa Üniversitesi, Ziraat Fakültesi, Yayın No: 24, Tokat.

Hassan, K. 2013. Improving the Marketing System Performance of Fruits and Vegetables in Bangladesh. Workshop on 'Research to Inform Food and Nutrition Security Policies' 3- 4 of July 2013, Dhaka.

Hussein, S., K., Venkatram, R., Ashok, K.R. 2013. Marketing Margin and Pricing Efficiency Analysis of Tomato Production in Sudan. Research Journal of Economic \& Business Studies, 2 (12):13-21.

İnan, İ.H. 2006. Tarım Ekonomisi ve İșletmeciliği. Trakya Üniversitesi, Ziraat Fakültesi, Tekirdağ.

İnan, İ.H. 1994. Tarım Ekonomisi, Trakya Üniversitesi, Ziraat Fakültesi, Yayın No: 30, Tekirdağ

Karagölge, C. 1995. Tarım Ekonomisi Temel İlkeleri, Atatürk Üniversitesi, Ziraat Fakültesi, Yayın No: 324, Erzurum.
Longwe, A., Magisoni, J.h:, Mloza-Banda, H.R., Singa, D.D., Ferguson, A. Snapp, S. 2010. Market Potential and Margins of Irrigated Beans: Cafe of Chingale Area Development Program in Southern Malawi, 4(1):9-11.

Miran, B. 2003. Temel İstatistik. Ege Üniversitesi, Ziraat Fakültesi, İzmir.

Murthy, D.S., Gajanana, T. M., Dakshinamoorthy, V. 2007. Marketing Losses and Their Impact on Marketing Margins: A Case Study of Banana in Karnataka. Agricultural Economics Research Review, 20: 47-60.

Murthy, D.S., Gajanana, T.M., Sudha, M., Dakshinamoorthy, V. 2009. Marketing and Post Harvet Losses in Fruits: Its Implications on Availability and Economy. Indian Journal of Agricultural Economics, 64(2): 259-275.

Newbold, P. 1995. Statistics for Business and Economics, Prentice-Hall, New Jersey

Oğuz, C., Kaçayır, F. 2009. Türkiye'de Elma Üretimi, Tüketimi, Pazar Yapısı ve Dış Ticareti Üzerine Bir Araşıtırma. Tarım Bilimleri Araştırma Dergisi, 2 (1):41-49.

TÜİK. 2015. Tarım İstatistikleri. http:www.tuik.gov.tr 